\title{
The prevalence, vancomycin resistance and virulence gene profiles of Enterococcus species recovered from different foods of animal origin
}

\author{
Mehmet Elmalı, and Hayriye Y. Can* \\ Department of Food Hygiene and Technology, Faculty of Veterinary Medicine, Mustafa Kemal University, \\ Hatay, Turkey
}

ELMALI, M., H. Y. CAN: The prevalence, vancomycin resistance and virulence gene profiles of Enterococcus species recovered from different foods of animal origin. Vet. arhiv 88, 111-124, 2018.

\section{ABSTRACT}

In this study, Enterococcus faecium was the most commonly found species with a level of $10.1 \%$, followed by Enterococcus durans (19/246, 7.7\%), Enterococcus faecalis (13/246, 5.2\%), and Enterococcus hirae (9/246, $3.6 \%)$. When the virulence gene profile of isolates was evaluated, gelE was the predominant $(25 / 66,37.8 \%)$ virulence factor in isolates followed by asal (22/66, 33.3\%), esp (12/66, 18.1\%), and cylA (4/66, 6.0\%). None of the isolates harboured the hyl gene. In this study, all and/or the majority of the Enterococcus isolates tested were found to be resistant to ampicillin, rifampicin, vancomycin, and erythromycin. However, vancomycin resistance genes, such as $\operatorname{van} B$ and $\operatorname{van} C 1$, were not determined in any of the isolates by multiplex PCR. Only three isolates of $E$. durans recovered from Surk cheese were found to be carrying the vanA gene. The results demonstrate that antimicrobial-resistant and virulent strains of enterococci occur in food of animal origin in Turkey.

Key words: antibiotic resistance; cheese, Enterococcus; tuf gene; virulence

\section{Introduction}

Enterococci are Gram-positive, catalase-negative, thermotolerant, facultative anaerobic bacteria. The gastrointestinal tracts of humans and animals serve as a primary host of these bacteria. Moreover, enterococci are ubiquitous bacteria that are also found in soil, water, vegetables and animal foods. They have the ability to grow at a wide range of temperatures and $\mathrm{pH}$ values. Enterococci are relatively resistant to heat processing and may survive during classic milk pasteurization and cause spoilage (FRANZ et al., 1999; AARESTRUP et al., 2000; HAYES et al., 2003; BUSANI et al., 2004; SANTESTEVAN et al., 2015).

*Corresponding author:

Assist. Prof. Dr. Hayriye Y. Can, Department of Food Hygiene and Technology, Faculty of Veterinary Medicine, Mustafa Kemal University, 31060 Alahan-Antakya/Hatay, Turkey, Phone: +90 32624558 45; Fax: +90 3262455704 ; E-mail: yesimcan@mku.edu.tr

ISSN 0372-5480

Printed in Croatia 
Enterococci have been known as indicators of fecal contamination. On the other hand, fermented meat and dairy products usually contain enterococci at different levels. Since they are important for ripening and flavor development in fermented foods, their presence is not considered as an indicator of fecal contamination in such kinds of foods. Some Enterococcus species have probiotic properties and also produce bacteriocins. Again, some enterococci are therapeutically used in the treatment of gastroenteritis in humans and animals. On the other hand, enterococci are considered as important nosocomial pathogens, because they cause bacteraemia, endocarditis, urinary tract and neonatal infections (FRANZ et al., 1999; RADU et al., 2001; GOMES et al., 2008; FRAZZON et al., 2010).

Enterococci have increasing resistance to antibiotics used in clinical practice. As they cause nosocomial infections, an important concern is the occurrence of difficulties in the treatment of infections in humans. In enterococci, antimicrobial resistance is acquired by gene transfer systems or is found intrinsically. Vancomycin resistance has been described as transferable by conjugation. It has been suggested that excessive use of antibiotics in clinical practice has led to the emergence of vancomycin-resistant enterococci (VRE). VRE were first isolated in Europe and quickly spread to the USA (AARESTRUP et al., 2000; SCHOUTEN et al., 2000; HAYES et al., 2003; BUSANI et al., 2004; JUNG et al., 2007; FRAZZON et al., 2010).

The occurence of antimicrobial resistant enterococci has been identified in food animals. As a result, food of animal origin may be a source of resistant enterococci. Antibiotic resistance genes may be transferred to humans via foods (FRANZ et al., 1999; ROBREDO et al., 2000; RADU et al., 2001). Therefore, it is very important to detect the presence of resistant enterococci in foods. For better understanding of the pathogenesis of enterococci, both antibiotic resistance and virulence gene profiles should be considered together. In Turkey, information about the occurence of virulent and antimicrobial resistant enterococci in food of animal origin is limited. Therefore, the present study was conducted to determine the prevalence, antibiotic resistance and virulence gene profiles of Enterococcus species in different foods of animal origin.

\section{Materials and methods}

Sample collection. In this study, a total of 225 samples, including 40 ground beef, 40 frozen broiler wing meat, 30 Carra cheese, 30 Surk cheese, 30 Künefe cheese, and 55 cow's milk (bulk tank milk) samples, were obtained in the province of Hatay. The samples were brought to the laboratory under cold chain and analysed microbiologically on the same day. 
Isolation and identification of enterococci. In this study, isolation of vancomycinsusceptible enterococci (VSE) and vancomycin-resistant enterococci (VRE) was performed using the classical culture method, as described below (OXOID, 2014).

For the isolation of VSE strains, $10 \mathrm{~g}$ and/or $10 \mathrm{~mL}$ of each sample were suspended in $90 \mathrm{~mL}$ of VRE broth (Oxoid, Basingstoke, Hampshire, England) supplemented with meropenem (Oxoid) and incubated at $37^{\circ} \mathrm{C}$ for $18-22 \mathrm{~h}$. Then, a loopful of growth was plated on VRE agar (Oxoid) and incubated at $37^{\circ} \mathrm{C}$ for $24-48 \mathrm{~h}$.

For isolation of the VRE strains, $10 \mathrm{~g}$ and/or $10 \mathrm{~mL}$ of each sample were added to $90 \mathrm{~mL}$ of VRE broth containing meropenem, and incubated at $37^{\circ} \mathrm{C}$ for $18-22 \mathrm{~h}$. After incubation, a loopful of growth was streaked onto VRE agar supplemented with vancomycin (Oxoid) and incubated at $37^{\circ} \mathrm{C}$ for $24-48 \mathrm{~h}$.

Typical colonies for enterococci (grey and/or pale brown colonies with black halos) from VRE agar were randomly collected and then, the following tests were applied to these colonies: Gram staining, catalase production, hemolytic activity, growth on Brain Heart Infusion agar (Oxoid) supplemented with $6.5 \%$ (w/v) NaCI. After identification of Enterococcus spp. and VRE by the classical culture method, isolates were stored at -20 ${ }^{\circ} \mathrm{C}$ until the PCR analysis.

PCR analysis. For PCR analysis, DNA extraction from the isolates was performed using a Bacterial DNA Extraction kit (Nucleic Acid Extraction Kit, Vivantis, Malaysia), following the manufacturer's instructions. After the extraction, all DNA's were stored at $-20{ }^{\circ} \mathrm{C}$ until the PCR confirmation.

Confirmation of enterococci at genus level by PCR assay. All Enterococcus isolates were confirmed by PCR based on the detection of the genus specific tuf gene. In this study, Ent1 and Ent2 primers (Ella Biotech GmbH, Martinsried, Germany) described by KE et al. (1999) were used (Table 1). For the PCR assay, reaction mixture and amplification conditions were performed as by KASIMOGLU-DOGRU et al. (2010).

Confirmation of enterococci at species level by multiplex PCR assay. For confirmation of Enterococcus faecalis, Enterococcus faecium, Enterococcus hirae, and Enterococcus durans, primer pairs reported by CHENG et al. (1997), KARIYAMA et al. (2000), and JACKSON et al. (2004) were used. The sequences of these primers are shown in Table 1.

In the multiplex PCR analysis, two different reaction mixtures, described by KASIMOGLU-DOGRU et al. (2010), were carried out. DNA amplification conditions suggested by KARIYAMA et al. (2000) were used for detection of E. faecalis and $E$. faecium, while for E. hirae and E. durans, JACKSON et al. (2004) thermal cycling protocol was adopted.

Molecular analysis of virulence genes among the E. faecalis, E. faecium, E. hirae and E. durans isolates. Virulence genes (asal, gelE, cylA, esp and hyl) were determined 
by multiplex PCR in all E. faecalis, E. faecium, E. hirae and E. durans isolates. Specific primers described by VANKERCKHOVEN et al. (2004), COQUE et al. (1995), WILLEMS et al. (2001) were used for this purpose (Table 1). PCR reaction mixture and amplification conditions were carried out according to VANKERCKHOVEN et al. (2004) and BUYUKYORUK et al. (2014), as previously reported.

Table 1. Specific primers used for identificaton of Enterococcus isolates, detection of virulence and vancomycin resistance genes among the isolates in the present study

\begin{tabular}{|c|c|c|c|}
\hline Genes & Sequence $\left(5^{\prime}-3^{\prime}\right)$ & Size (bp) & References \\
\hline tuf & $\begin{array}{l}\text { Ent1- TACTGACAAACCATTCATGATG } \\
\text { Ent2- AACTTCGTCACCAACGCGAAC }\end{array}$ & 112 & Ke et al. (1999) \\
\hline$d d l_{\text {E. faecalis }}$ & $\begin{array}{l}\text { ddlE1-ATCAAGTACAGTTAGTCTTTATTAG } \\
\text { ddlE2-ACGATTCAAAGCTAACTGAATCAGT }\end{array}$ & 941 & $\begin{array}{l}\text { Kariyama et al. } \\
(2000)\end{array}$ \\
\hline$d d l_{\text {E.faecium }}$ & $\begin{array}{l}\text { ddlF1- TTGAGGCAGACCAGATTGACG } \\
\text { ddlF2- TATGACAGCGACTCCGATTCC }\end{array}$ & 658 & Cheng et al. (1997) \\
\hline$d d l_{E \text {. durans }}$ & $\begin{array}{l}\text { DU1- CCTACTGATATTAAGACAGCG } \\
\text { DU2- TAATCCTAAGATAGGTGTTTG }\end{array}$ & 295 & Jackson et al. (2004) \\
\hline$d d l_{\text {E. hirae }}$ & $\begin{array}{l}\text { HI1- CTTTCTGATATGGATGCTGTC } \\
\text { HI2- TAAATTCTTCCTTAAATGTTG }\end{array}$ & 187 & Jackson et al. (2004) \\
\hline asal & $\begin{array}{l}\text { ASA11- GCACGCTATTACGAACTATGA } \\
\text { ASA12- TAAGAAAGAACATCACCACGA }\end{array}$ & 375 & $\begin{array}{l}\text { Vankerckhoven et al. } \\
(2004)\end{array}$ \\
\hline gelE & $\begin{array}{l}\text { GEL11- TATGACAATGCTTTTTGGGAT } \\
\text { GEL12- AGATGCACCCGAAATAATATA }\end{array}$ & 213 & $\begin{array}{l}\text { Vankerckhoven et al. } \\
(2004)\end{array}$ \\
\hline cylA & $\begin{array}{l}\text { CYT I- ACTCGGGGATTGATAGGC } \\
\text { CYT IIb- GCTGCTAAAGCTGCGCTT }\end{array}$ & 688 & Coque et al. (1995) \\
\hline$e s p$ & $\begin{array}{l}\text { ESP 14F- AGATTTCATCTTTGATTCTTGG } \\
\text { ESP 12R- AATTGATTCTTTAGCATCTGG }\end{array}$ & 510 & Willems et al. (2001) \\
\hline hyl & $\begin{array}{l}\text { HYL n1- ACAGAAGAGCTGCAGGAAATG } \\
\text { HYL n2- GACTGACGTCCAAGTTTCCAA }\end{array}$ & 276 & $\begin{array}{l}\text { Vankerckhoven et al. } \\
(2004)\end{array}$ \\
\hline vanA & $\begin{array}{l}\text { A1- CATGAATAGAATAAAAGTTGCAATA } \\
\text { A2- CCCCTTTAACGCTAATACGATCAA }\end{array}$ & 1030 & Evers et al. (1993) \\
\hline $\operatorname{van} B$ & $\begin{array}{l}\text { B1- GTGACAAACCGGAGGCGAGGA } \\
\text { B2- CCGCCATCCTCCTGCAAAAAA }\end{array}$ & 433 & $\begin{array}{l}\text { Handwerger et al. } \\
(1992)\end{array}$ \\
\hline $\operatorname{vanCl}$ & $\begin{array}{l}\text { C1- GGTATCAAGGAAACCTC } \\
\text { C2- CTTCCGCCATCATAGCT }\end{array}$ & 822 & $\begin{array}{l}\text { Dutka-Malen et al. } \\
\text { (1995) }\end{array}$ \\
\hline
\end{tabular}

Determination of antimicrobial susceptibility. All Enterococcus isolates were tested for susceptibility to the following antibiotics, using the disk diffusion method: ampicillin $(10 \mu \mathrm{g} / \mathrm{disc})$, streptomycin $(300 \mu \mathrm{g} / \mathrm{disc})$, gentamicin $(120 \mu \mathrm{g} / \mathrm{disc})$, chloramphenicol (30 $\mu \mathrm{g} / \mathrm{disc})$, rifampicin $(5 \mu \mathrm{g} / \mathrm{disc})$, ciprofloxacin $(5 \mu \mathrm{g} / \mathrm{disc})$, erythromycin $(15 \mu \mathrm{g} / \mathrm{disc})$, and vancomycin $(30 \mu \mathrm{g} / \mathrm{disc})$. The results were interpreted according to the Clinical and Laboratory Standards Institute (CLSI) guidelines (CLSI, 2013). 
PCR amplification of vancomycin resistance genes. Specific primer pairs were selected for vancomycin resistance genes (vanA, vanB, and vanC1) according to EVERS et al. (1993), HANDWERGER et al. (1992), and DUTKA-MALEN et al. (1995) (Table 1). PCR analysis was conducted according to KARIYAMA et al. (2000).

\section{Results}

In this study, a total of 225 samples were examined and $155(68.8 \%)$ of them were found to be contaminated with Enterococcus spp. Enterococci were isolated from 52 (57.7\%), $33(60 \%), 33(82.5 \%)$, and $37(92.5 \%)$ cheese, raw milk, broiler meat, and ground beef samples, respectively. A total of 246 isolates were confirmed as Enterococcus spp. by PCR, based on the detection of the tuf gene (Fig. 1).

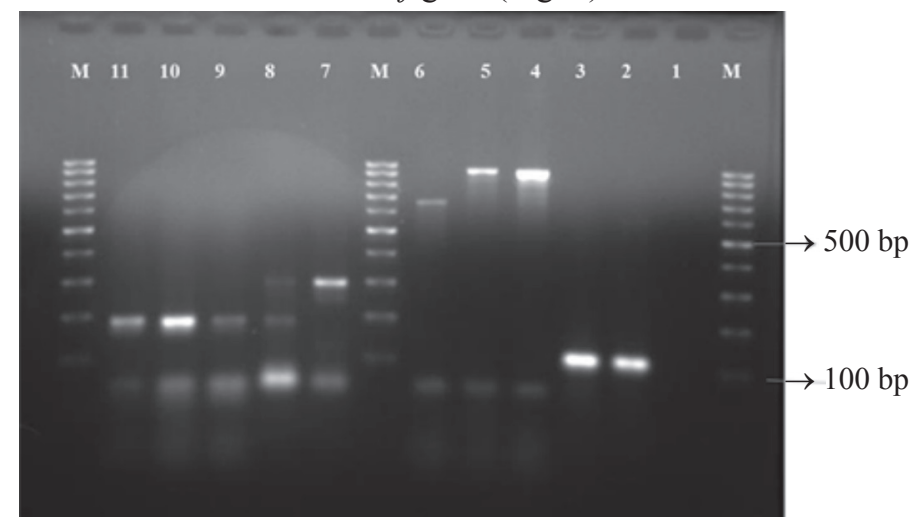

Fig. 1. Electrophorese image of Enterococcus spp., E. fecalis, E. faecium, E. hirae, and E. durans strains. [M: 100 bp DNA marker (Bioron); 1: Negative control; 2 and 3: Enterococcus spp. (112 bp); 4 and 5: E. faecalis (941 bp); 6: E. faecium (658 bp); 7: E. durans (295 bp); 8: E. hirae+E. durans (mixed culture); 9-11: E. hirae (187 bp)].

Of the isolated enterococci, 90 were recovered from cheese samples, 63 from ground beef, 51 from raw cow's milk, and 42 from broiler wing meat. High levels of contamination with Enterococcus spp. was detected in cheese samples (90/246, 36.5\%), followed by ground beef $(63 / 246,25.6 \%)$, raw milk $(51 / 246,20.7 \%)$, and broiler meat $(42 / 246,17 \%)$. Among the 246 enterococci isolated, 58.13\% were determined as VSE and $41.86 \%$ were VRE. VSE contamination was detected at a rate of $65.5 \%(59 / 90), 63.4 \%(40 / 63), 50.9 \%$ $(26 / 51), 42.8 \%(18 / 42)$ in cheese, ground beef, raw milk, and broiler wing meat samples, respectively. In contrast, VRE contamination was detected more frequently in broiler meat $(24 / 42,57.1 \%)$, followed by raw milk $(25 / 51,49 \%)$, ground beef $(23 / 63,36.5 \%)$, and cheese $(31 / 90,34.4 \%)$ samples (Table 2$)$. 
M. Elmalı and H. Y. Can: Vancomycin resistance and virulence gene profiles of Enterococcus

Table 2. Distribution of Enterococcus isolates at species level and in terms of vancomycin resistance

\begin{tabular}{|c|c|c|c|c|c|c|c|c|c|c|c|c|}
\hline \multirow[b]{3}{*}{ Species } & \multicolumn{12}{|c|}{ No. of isolates from: } \\
\hline & \multicolumn{2}{|c|}{$\begin{array}{l}\text { Künefe } \\
\text { cheese }\end{array}$} & \multicolumn{2}{|c|}{$\begin{array}{c}\text { Ground } \\
\text { beef }\end{array}$} & \multicolumn{2}{|c|}{$\begin{array}{c}\text { Broiler } \\
\text { meat }\end{array}$} & \multicolumn{2}{|c|}{$\begin{array}{c}\text { Carra } \\
\text { cheese }\end{array}$} & \multicolumn{2}{|c|}{$\begin{array}{c}\text { Surk } \\
\text { cheese }\end{array}$} & \multicolumn{2}{|c|}{$\begin{array}{l}\text { Raw } \\
\text { milk }\end{array}$} \\
\hline & VSE* & VRE** & VSE & VRE & VSE & VRE & VSE & VRE & VSE & VRE & VSE & VRE \\
\hline E. hirae & 0 & 0 & 6 & 1 & 0 & 0 & 0 & 0 & 0 & 0 & 2 & 0 \\
\hline E. durans & 3 & 2 & 0 & 1 & 1 & 0 & 3 & 0 & 3 & 1 & 5 & 0 \\
\hline E. faecalis & 0 & 0 & 8 & 1 & 0 & 1 & 1 & 0 & 0 & 0 & 2 & 0 \\
\hline E. faecium & 2 & 0 & 7 & 6 & 0 & 1 & 2 & 1 & 0 & 0 & 2 & 4 \\
\hline \begin{tabular}{|l|} 
E. hirae + \\
E. durans \\
\end{tabular} & 0 & 0 & 0 & 0 & 0 & 0 & 0 & 0 & 0 & 0 & 1 & 1 \\
\hline $\begin{array}{l}\text { E. faecalis }+ \\
\text { E. faecium }\end{array}$ & 0 & 0 & 9 & 0 & 0 & 0 & 3 & 0 & 0 & 0 & 2 & 0 \\
\hline $\begin{array}{l}\text { Other enterococcal } \\
\text { species }\end{array}$ & 21 & 17 & 10 & 14 & 17 & 22 & 10 & 1 & 11 & 9 & 12 & 20 \\
\hline Total & 26 & 19 & 40 & 23 & 18 & 24 & 19 & 2 & 14 & 10 & 26 & 25 \\
\hline
\end{tabular}

*VSE: Vancomycin-susceptible, **VRE: Vancomycin-resistant

All isolates were identified at species level by multiplex PCR assay and E. faecium was the most commonly found species, with a level of $10.1 \%(25 / 246)$, followed by E. durans (19/246, 7.7\%), E. faecalis (13/246, 5.2\%) and E. hirae (9/246, 3.6\%). One hundred and sixty-four of those isolates $(66.6 \%)$ were detected as other enterococcal species. E. faecalis, E. faecium and E. hirae were isolated more frequently from ground beef and raw milk, while $E$. durans was isolated more frequently from cheese samples. Also, among the isolates, 6.5\% (16/246) were found as mixed cultures (E. hirae $+E$. durans and E. faecalis $+E$. faecium) that were detected in raw milk, ground beef, and Carra cheese samples (Table 2).

Only pure cultures of isolates E. faecalis, E. faecium, E. hirae and E. durans were analysed for the presence of virulence genes by multiplex PCR (Fig. 2), while mixed cultures of enterococcal isolates were excluded. In the present study, gelE was the predominant $(25 / 66,37.8 \%)$ virulence factor in the isolates, followed by asal $(22 / 66$, $33.3 \%)$, esp $(12 / 66,18.1 \%)$, and $c y l A(4 / 66,6.0 \%)$. However, none of the isolates were harbouring $h y l$ gene. Virulence genes were more frequent in E. faecalis than in E. faecium, E. durans, and E. hirae. Also, in the present study, some of the isolates carried more than one virulence gene, as shown in Table 3 . 
M. Elmalı and H. Y. Can: Vancomycin resistance and virulence gene profiles of Enterococcus

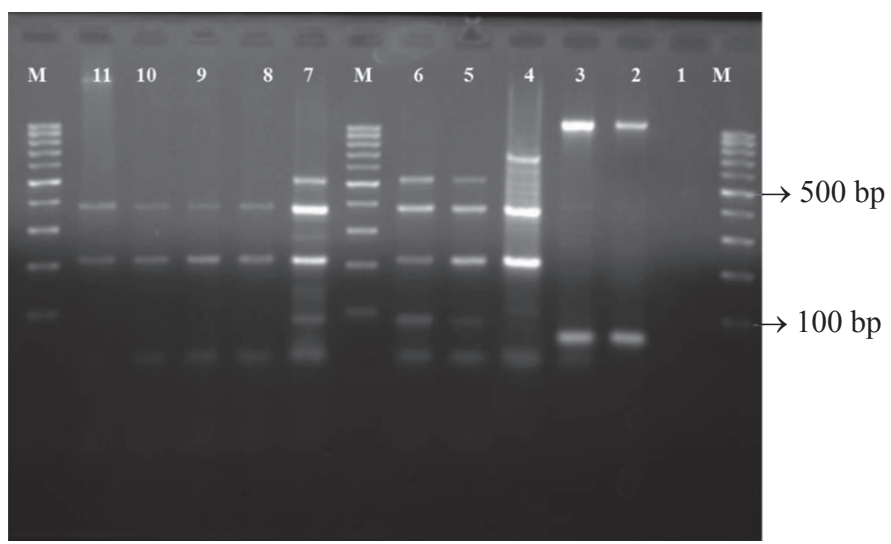

Fig. 2. PCR analysis of the virulence and vancomycin resistance genes of the enterococci isolates. M: 100 bp DNA marker (Bioron); 1: Negative control; 2 and 3: van $A(+)$ isolates (1030 bp); 4: gelE (213 bp)+asal (375 bp)+cylA (688 bp) positive isolate; 5, 6 and 7: gelE+asal+esp (510 bp) positive isolates; 8-11: gelE+asal positive isolates.

Table 3. Occurence of virulence genes among the E. faecalis, E. faecium, E. hirae and E. durans strains

\begin{tabular}{|c|c|c|c|c|c|c|c|c|c|c|}
\hline \multirow[b]{2}{*}{ Isolate (n) } & \multicolumn{10}{|c|}{ Virulence genes } \\
\hline & asal & gelE & $\begin{array}{c}\text { asal } \\
+ \text { gelE }\end{array}$ & $\begin{array}{l}\text { asal } \\
+e s p\end{array}$ & $\begin{array}{l}\text { gelE } \\
+e s p \\
\end{array}$ & $\begin{array}{l}\text { cylA } \\
+e s p\end{array}$ & $\begin{array}{c}\text { asal+ } \\
\text { gelE+esp }\end{array}$ & $\begin{array}{c}\text { asal+ } \\
\text { gelE }+ \text { cylA }\end{array}$ & $\begin{array}{l}\text { asal+gelE } \\
+c y l A+e s p\end{array}$ & None \\
\hline $\begin{array}{l}\text { E. faecium } \\
\text { (25) }\end{array}$ & 1 & 2 & 2 & - & 1 & - & 2 & - & - & 17 \\
\hline $\begin{array}{l}\text { E. durans } \\
\text { (19) }\end{array}$ & 1 & 1 & 2 & - & 2 & 1 & 1 & 1 & - & 10 \\
\hline $\begin{array}{l}\text { E. faecalis } \\
\text { (13) }\end{array}$ & - & 1 & 3 & 1 & - & - & 2 & 1 & 1 & 4 \\
\hline $\begin{array}{l}\text { E. hirae } \\
(9)\end{array}$ & - & - & 3 & 1 & - & - & - & - & - & 5 \\
\hline $\begin{array}{l}\text { Total } \\
(66)\end{array}$ & 2 & 4 & 10 & 2 & 3 & 1 & 5 & 2 & 1 & 36 \\
\hline
\end{tabular}

A total of 230 Enterococcus isolates were phenotypically tested for their antibiotic resistance profiles, using the disc diffusion method, and the results were evaluated according to CLSI (2013). However, 16 isolates which were detected as mixed cultures were not analysed by the antibiotic susceptibility test. In this study, all and/or the majority of the Enterococcus isolates tested were found to be resistant to ampicillin, rifampicin, 
vancomycin, and erythromycin. The most effective antibiotic was gentamicin, because $100 \%$ of the isolates were susceptible to it. Also, $98.2 \%, 81.7 \%$, and $72.1 \%$ of the isolates were susceptible to streptomycin, chloramphenicol, and ciprofloxacin, respectively (Table 4).

Table 4. Antimicrobial susceptibility of Enterococcus isolates obtained from raw cow's milk, ground beef, broiler wing meat, and traditional cheese samples

\begin{tabular}{|c|c|c|c|c|c|c|c|c|c|c|c|c|c|c|c|}
\hline \multirow[b]{2}{*}{ Antibiotic } & \multicolumn{3}{|c|}{$\begin{array}{l}\text { E. faecalis } \\
(\mathrm{n}=13)\end{array}$} & \multicolumn{3}{|c|}{$\begin{array}{l}\text { E. faecium } \\
(\mathrm{n}=25)\end{array}$} & \multicolumn{3}{|c|}{$\begin{array}{c}\text { E. hirae } \\
(\mathrm{n}=9)\end{array}$} & \multicolumn{3}{|c|}{$\begin{array}{c}\text { E. durans } \\
(\mathrm{n}=19)\end{array}$} & \multicolumn{3}{|c|}{$\begin{array}{c}\text { Other enterococcal } \\
\text { species }(n=164)\end{array}$} \\
\hline & $\mathrm{R}$ & I & $\mathrm{S}$ & $\mathrm{R}$ & I & $\mathrm{S}$ & $\mathrm{R}$ & I & $\mathrm{S}$ & $\mathrm{R}$ & I & $\mathrm{S}$ & $\mathrm{R}$ & I & $\mathrm{S}$ \\
\hline Ampicillin & 12 & 0 & 1 & 25 & 0 & 0 & 7 & 0 & 2 & 19 & 0 & 0 & 162 & 0 & 2 \\
\hline Rifampicin & 12 & 1 & 0 & 25 & 0 & 0 & 9 & 0 & 0 & 19 & 0 & 0 & 158 & 4 & 2 \\
\hline Vancomycin & 12 & 1 & 0 & 25 & 0 & 0 & 9 & 0 & 0 & 18 & 0 & 1 & 150 & 9 & 5 \\
\hline Erythromycin & 13 & 0 & 0 & 25 & 0 & 0 & 8 & 1 & 0 & 18 & 1 & 0 & 154 & 10 & 0 \\
\hline Streptomycin & 1 & 0 & 12 & 2 & 0 & 23 & 0 & 0 & 9 & 0 & 0 & 19 & 1 & 0 & 163 \\
\hline Chloramphenicol & 1 & 2 & 10 & 1 & 3 & 21 & 0 & 3 & 6 & 1 & 3 & 15 & 10 & 18 & 136 \\
\hline Ciprofloxacin & 2 & 7 & 4 & 4 & 9 & 12 & 0 & 5 & 4 & 0 & 3 & 16 & 7 & 27 & 130 \\
\hline Gentamicin & 0 & 0 & 13 & 0 & 0 & 25 & 0 & 0 & 9 & 0 & 0 & 19 & 0 & 0 & 164 \\
\hline
\end{tabular}

$\mathrm{n}$ : number of isolate; R: resistant; I: intermediately resistant; S: susceptible.

In the present study, almost all the E. faecalis, E. faecium, E. durans, and E. hirae isolates were phenotypically resistant to vancomycin by the disc diffusion method, but vancomycin resistance genes such as $v a n B$ and vanCl genes were not determined in any of the isolates by multiplex PCR. Only three isolates of E. durans obtained from Surk cheese samples were found to be carrying the vanA gene. Overall, vanA gene was detected in $4.5 \%(3 / 66)$ of the isolates tested in our study.

\section{Discussion}

In our study, the most frequently isolated species from samples was E. faecium and it was found that E. faecalis had more virulence genes than other Enterococcus species. E. faecium, E. faecalis, and E. hirae were more often found in raw ground beef and milk, while E. durans was generally isolated from cheese. Also, in this study, contamination with Enterococcus was most commonly detected in cheese samples.

KASIMOGLU-DOGRU et al. (2010) found that $78 \%$ of chicken neck skin is contaminated with Enterococcus spp. BUYUKYORUK et al. (2014) found that $73.6 \%$ of cheese samples and KOLUMAN et al. (2009) found that $50 \%$ of 200 different food samples were contaminated with Enterococcus spp.

In contrast to our study, BUYUKYORUK et al. (2014), ÇITAK et al. (2004), KOLUMAN et al. (2009) generally found E. faecalis and E. faecium in cheese. In our 
study, the tested cheeses were traditional and thus, this difference might be due to different cheese production techniques (for example, using raw or pasteurized milk in production).

Similarly, KASIMOGLU-DOGRU et al. (2010) most often isolated E. faecium from samples and also observed E. durans, E. faecalis and E. hirae. However, they could not determine either phenotypically or genotypically vancomycin resistance in isolates. Again, the study of ÖZMEN TOĞAY et al. (2010) did not detect vanB gene in isolates, similar to our study; but they detected the vanA gene in E. faecalis strains that were isolated from cheese and sausage. In this study, $v a n B$ and $v a n C 1$ genes encoding vancomycin resistance were not detected genotypically in any of the isolates, while the vanA gene was seen in isolates obtained from Surk cheese. In this context, it may be better to investigate the presence of other genes such as: vanC2, vanC3, vanD, vanE and vanG, encoding vancomycin resistance in Enterococcus.

In accordance with ÖZMEN TOĞAY et al. (2010) and BUYUKYORUK et al. (2014), the gelE virulence gene was most commonly detected in isolates, and some isolates carried more than one virulence gene at the same time. SANTESVAN et al. (2015) detected ace, gelE, asa and cylA genes with percentages of $68 \%, 54 \%, 22 \%$ and $4 \%$ in enterococci recovered from fecal samples of wild fur seals. GOMES et al. (2008) detected a much higher prevalence of virulence genes in the E. faecalis isolates and the $h y l$ gene was not determined in any of their isolates, corroborating the results of our study.

In our study, VSE were most frequently isolated from cheese and VRE were most frequently detected in broiler meat. Similarly, KOLUMAN et al. (2009) detected VRE most frequently in chicken meat. When compairing studies done in other countries, consistent with our study, GOMES et al. (2008) reported that cheese and meat samples are generally contaminated with Enterococcus and, in those samples, the dominant strain is E. faecium. Furthermore, they detected virulence genes at a higher rate in E. faecalis when compared with other Enterococcus species, and they did not find the hyl gene in isolates. Similarly, HAYES et al. (2003) detected E. faecium, E. faecalis, and E. hirae in raw meat samples, in increasing order. ROBREDO et al. (2000), found VRE in chicken meat at a rate of $27.2 \%$, which was lower than in our study. ROBREDO et al. (2000) mentioned that the contamination of foods with VRE can be important for VRE-related infections in humans.

JUNG et al. (2007) determined genes encoding vancomycin resistance (vanA, vanC1, vanC2) with PCR, in Enterococcus strains that were isolated from different animal resources in Korea, and they reported E. faecium carrying the vanA gene to be high in poultry. Also, in a study by RADU et al. (2001), poultry samples obtained from local markets in Malaysia were found to be generally contaminated with E. faecalis. In addition, E. durans, E. hirae, E. faecium, and E. casseliflavus were also found in the samples they analized. It was reported that all of the isolates were multidrug resistance 
M. Elmalı and H. Y. Can: Vancomycin resistance and virulence gene profiles of Enterococcus

enterococci. E. faecalis, E. durans, E.hirae, and E. faecium strains were detected as vancomycin-resistant with the disc diffusion method, and all of them were found to have the van $A$ gene genotypically. Similarly, $v a n B$ and van $C 1$ genes were not detected in the isolates.

From the results of the antibiotic susceptibility test, gentamicin was found to be the most effective drug for Enterococcus because all the isolates were 100\% susceptible to gentamicin. In contrast to our findings, ÇITAK et al. (2004), KASIMOGLU-DOGRU et al. (2010), ÖZMEN TOĞAY et al. (2010), ROBREDO et al. (2000), and HAYES et al. (2003) reported a high-level of aminoglycoside (gentamicin, streptomycin) resistance in their studied isolates. However, ÇITAK et al. (2004) reported high levels of vancomycin and erythromycin resistance among their isolates, which is similar to our findings, whereas KOLUMAN et al. (2009) detected low levels of vancomycin and erythromycin resistance in their study. Again, studies in Brazil (GOMES et al., 2008; FRAZZON et al., 2010), the United States of America (HAYES et al., 2003), and Denmark (AARESTRUP et al., 2000) reported very low levels of vancomycin resistance, or did not detect any resistance in isolates.

In Brazil, GOMES et al. (2008) found that all the E. faecalis and E. faecium isolates were susceptible to ampicillin, while FRAZZON et al. (2010) found resistant strains. In our study, all E. faecium and E. durans isolates and $92.3 \%$ of E. faecalis and $77.7 \%$ of E. hirae isolates were resistant to ampicillin. In contrast, ampicillin and chloramphenicol were the most effective antibiotics against Enterococcus in Malaysia (RADU et al., 2001).

Furthermore, FRAZZON et al. (2010) detected high levels of erythromycin resistance, especially in strains that were isolated from chicken meat, and ascribed this finding to usage of erythromycin in poultry farming for therapeutic purposes. Again, in seals with fur that are seen along the Brazilian coast, antibiotic-resistant Enterococcus strains were detected. It was found that these strains had both erythromycin and tetracycline resistance encoding genes and some virulence genes. As a result, these animals are reported to be a reservoir for antibiotic-resistant Enterococcus and could play role in the environmental spread of these strains (SANTESTEVAN, 2015).

In Denmark, chloramphenicol resistance was widely found among the E. faecalis and E. faecium strains isolated from stool samples of people with diarrhea, and broilers and pigs. All the human isolates were reported to be susceptible to vancomycin, and the strains obtained from the two other sources (broilers and pigs) were reported to be resistant at a ratio of $10 \%$ and $17 \%$, respectively. Differently, all vancomycin-resistant strains were found to have the vanA gene (AARESTRUP et al., 2000).

A study was conducted in Europe in 1997 to determine the vancomycin resistance of Enterococcus strains isolated from humans, and the presence of genes encoding this resistance. In this context, 4208 clinical isolates were collected from 27 different countries, 
including Turkey. VRE strains carrying the vanA gene were most commonly found in England, with a ratio of $2.7 \%$, and isolates with the $v a n B$ gene were most commonly seen in Slovenia, with a ratio of $2 \%$. Isolates carrying the vanC gene were most frequently found in Turkey and Latvia, with ratios of $11.7 \%$ and $14.3 \%$, respectively. The highest gentamicin resistance was observed in clinical isolates obtained from Turkey and Greece (SCHOUTEN et al., 2000). In contrast, the vanC gene was not found in any of the isolates that were obtained from foodstuffs in our study. Interestingly, all of the isolates obtained from foodstuffs in our study were found to be susceptible to gentamicin. On this basis, we can say that the antibiotic resistance profiles of clinical isolates and Enterococcus isolates obtained from foodstuffs might show phenotypic and genotypic differences.

\section{Acknowledgements}

This study was suppported by the Department of Scientific Research Projects (Project code: 12407), Mustafa Kemal University, Turkey.

\section{References}

AARESTRUP, F. M., Y. AGERSO, P. GERNER-SMIDT, M. MADSEN, L. B. JENSEN (2000): Comparison of antimicrobial resistance phenotypes and resistance genes in Enterococcus faecalis and Enterococcus faecium from humans in the community, broilers, and pigs in Denmark. Diagn. Microbiol. Infect. Dis. 37, 127-137.

BUSANI, L., M. DEL GROSSO, C. PALADINI, C. GRAZIANI, A. PANTOSTI, F. BIAVASCO, A. CAPRIOLI (2004): Antimicrobial susceptibility of vancomycin- susceptible and -resistant enterococci isolated in Italy from raw meat products, farm animals, and human infections. Int. J. Food Microbiol. 97, 17-22.

BUYUKYORUK, S., N. D. AYAZ, Y. E. GENCAY, D. BEYAZ, P. KOCAK (2014): Species distribution, molecular characteristics and vancomycin resistance gene profiles of Enterococcus sp. isolates from farmhouse cheeses in western Turkey. Int. J. Dairy Tech. 67, 103-109.

CHENG, S., F. K. McCLESKEY, M. J. GRESS, J. M. PETROZIELLO, R. LIU, H. NAMDARI, K. BENINGA, A. SALMEN, V. G. DEL VECCHIO (1997): A PCR assay for identification of Enterococcus faecium. J. Clin. Microbiol. 35, 1248-1250.

CLSI (2013): Clinical and Laboratory Standards Institute. Performance standards for antimicrobial susceptibility testing; twenty-third informational supplement; Enterococcus spp. Wayne, P. A., 33, M02-M07.

COQUE, T. M., J. E. PATTERSON, J. M. STECKELBERG, B. E. MURRAY (1995): Incidence of hemolysin, gelatinase, and aggregation substance among enterococci isolated from patients with endocarditis and other infections and from feces of hospitalized and community-based persons. J. Infect. Dis. 171, 1223-1229. 
M. Elmalı and H. Y. Can: Vancomycin resistance and virulence gene profiles of Enterococcus

ÇITAK, S., N. YUCEL, S. ORHAN (2004): Antibiotic resistance and incidence of Enterococcus species in Turkish white cheese. Int. J. Dairy Tech. 57, 27-31.

DUTKA-MALEN, S., S. EVERS, P. COURVALIN (1995): Detection of glycopeptide resistance genotypes and identification to the species level of clinically relevant enterococci by PCR. J. Clin. Microbiol. 33, 24-27.

EVERS, S., D. F. SAHM, P. COURVALIN (1993): The vanB gene of vancomycin-resistant Enterococcus faecalis V583 is structurally related to genes encoding D-Ala: D-Ala ligases and glycopeptide-resistance proteins vanA and vanC. Gene 124, 143-144.

FRANZ, C. M. A. P., W. H. HOLZAPFEL, M. E. STILES (1999): Enterococci at the crossroads of food safety? Int. J. Food Microbiol. 47, 1-24.

FRAZZON, A. P. G., B. A. GAMA, V. HERMES, C. G. BIERHALS, R. I. PEREIRA, A. G. GUEDES, P. A. D'AZEVEDO, J. FRAZZON (2010): Prevalence of antimicrobial resistance and molecular characterization of tetracycline resistance mediated by $\operatorname{tet}(\mathrm{M})$ and $\operatorname{tet}(\mathrm{L})$ genes in Enterococcus spp. isolated from food in Southern Brazil. World J. Microbiol. Biotechnol. 26, 365-370.

GOMES, B. C., C. T. ESTEVES, I. C. V. PAlAzZO, A. L. C. DARINI, G. E. FELiS, L. A. SECHI, B. D. G. M. FRANCO, E. C. P. DE MARTINIS (2008): Prevalence and characterization of Enterococcus spp. isolated from Brazilian foods. Food Microbiol. 25, 668675 .

HANDWERGER, S., D. C. PERLMAN, D. ALTARAC, V. McAULIFFE (1992): Concomitant high-level vancomycin and penicillin resistance in clinical isolates of enterococci. Clin. Infect. Dis. 14, 655-661.

HAYES, J. R., L. L. ENGLish, P. J. CARTER, T. PROESCHOLDT, K. Y. LEE, D. D. WAGNER, D. G. WHITE (2003): Prevalence and antimicrobial resistance of Enterococcus species isolated from retail meats. App. Environ. Microbiol. 69, 7153-7160.

JACKSON, C. R., P. J. FEDORKA-CRAY, J. B. BARRET (2004): Use of a genus- and speciesspecific multiplex PCR for identification of enterococci. J. Clin. Microbiol. 42, 3558-3565.

JUNG, W. K., J. Y. LIM, N. H. KWON, J. M. KIM, S. K. HONG, H. C. KOO, S. H. KIM, Y. H. PARK (2007): Vancomycin-resistant enterococci from animal sources in Korea. Int. J. Food Microbiol. 113, 102-107.

KARIYAMA, R., R. MITSUHATA, J. W. CHOW, D. B. CLEWELL, H. KUMON (2000): Simple and reliable multiplex PCR assay for surveillance isolates of vancomycin-resistant enterococci. J. Clin. Microbiol. 38, 3092-3095.

KASIMOGLU-DOGRU, A., Y. E. GENCAY, N. D. AYAZ (2010): Prevalence and antibiotic resistance profiles of Enterococcus species in chicken at slaughter level; absence of vanA and vanB genes in E. faecalis and E. faecium. Res. Vet. Sci. 89, 153-158.

KE, D., F. J. PICARD, F. MARTINEAU, C. MENARD, P. H. ROY, M. OUELLETTE, M. G. BERGERON (1999): Development of a PCR assay for rapid detection of enterococci. J. Clin. Microbiol. 37, 3497-3503. 
M. Elmalı and H. Y. Can: Vancomycin resistance and virulence gene profiles of Enterococcus

KOLUMAN, A., L. S. AKAN, F. P. ÇAKIROĞLU (2009): Occurence and antimicrobial resistance of enterococci in retail foods. Food Control 20, 281-283.

OXOID (2014): Selective medias for the isolation of vancomycin resistant enterococci (VRE) and high level aminoglycoside resistant enterococci (HLARE) from clinica samples. Available from: http://www.oxoid.com. Accessed Apr. 25, 2016.

ÖZMEN TOĞAY, S., A. ÇELEBI KESKIN, L. AÇIK, A. TEMIZ (2010): Virulence genes, antibiotic resistance and plasmid profiles of Enterococcus faecalis and Enterococcus faecium from naturally fermented Turkish foods. J. Appl. Microbiol. 109, 1084-1092.

RADU, S., H. TOOSA, R. A. RAHIM, A. REEZAL, M. AHMAD, A. N. HAMID, G. RUSUL, M. NISHIBUCHI (2001): Occurrence of the vanA and vanC2/C3 genes in Enterococcus species isolated from poultry sources in Malaysia. Diagn. Microbiol. Infect. Dis. 39, 145-153.

ROBREDO, B., K. V. SINGH, F. BAQUERO, B. E. MURRAY, C. TORRES (2000): Vancomycin-resistant enterococci isolated from animals and food. Int. J. Food Microbiol. 54, 197-204.

SANTESTEVAN, N.A., D. A.ZVOBODA, J. PRICHULA, R. I. PEREIRA, G. R. WACHHOLZ, L. A. CARDoso, T. M. DEMOURA, A. W. MEDEIROS, D. B. DEAMORIN, M. TAVARES, P. A. D’AZEVEDO, A. C. FRANCO, J. FRAZZON, A. P. G. FRAZZON (2015): Antimicrobial resistance and virulence factor gene profiles of Enterococcus spp. isolates from wild Arctocephalus australis (South American fur seal) and Arctocephalus tropicalis (Subantarctic fur seal). World J. Microbiol. Biotechnol. 31, 1935-1946.

SCHOUTEN, M. A., J. A. A. HOOGKAMP-KORSTANJE, J. F. G. MEIS, A. VOSS, THE EUROPEAN VRE STUDY GROUP (2000): Prevalence of vancomycin-resistant enterococci in Europe. Eur. J. Clin. Microbiol. Infect. Dis. 19, 816-822.

VANKERCKHOVEN, V., T. V. AUTGAERDEN, C. VAEL, C. LAMMENS, S. CHAPELLE, R. ROSSI, D. JABES, H. GOOSSENS (2004): Development of a multiplex PCR for the detection of asal, gelE, cylA, esp, and hyl genes in enterococci and survey for virulence determinants among European hospital isolates of Enterococcus faecium. J. Clin. Microbiol. 42, 4473-4479.

WILLEMS, R. J. L., W. HOMAN, J. TOP, M. VANSANTEN-VERHEUVEL, D. TRIBE, X. MANZIOROS, C. GAILLARD, C. M. J. E. VANDENBROUCKE-GRAULS, E. M. MASCINI, E. VANKREGTEN, J. D. A. VANEMBDEN, M. J. M. BONTEN (2001): Variant esp gene as a marker of a distinct genetic lineage of vancomycin-resistant Enterococcus faecium spreading in hospitals. Lancet 357, 853-855.

Received: 5 September 2016

Accepted: 16 January 2017

Vet. arhiv 88 (1), 111-124, 2018 


\section{ELMALI, M., H. Y. CAN: Otpornost na vankomicin i geni za virulenciju u bakterija roda Enterococcus. Vet. arhiv 88, 111-124, 2018. \\ SAŽETAK}

Najčešće dokazana vrsta u ovom istraživanju bila je Enterococcus faecium s učestalošću od 10,1\%, zatim Enterococcus durans (19/246, 7,7 \%), Enterococcus faecalis (13/246, 5,2 \%) te Enterococcus hirae (9/246, 3,6 \%). U izolatima spomenutih vrsta pretežno je dokazan gen gelE za virulenciju (25/66, 37,8 \%), zatim gen asal $(22 / 66,33,3 \%)$, esp $(12 / 66,18,1 \%)$ te $c y l A(4 / 66,6,0 \%)$. Ni u jednog od izolata nije bio ustanovljen gen hyl. Gotovo svi ili većina izolata bila je otporna na ampicilin, rifampicin, vankomicin i eritromicin. Ipak, geni za otpornost na vankomicin, kao što su vanB i vanC1, nisu bili dokazani ni u jednom izolatu višestrukim PCRom. Samo tri izolata vrste $E$. durans, izdvojena iz surk sira, posjedovala su gen vanA. Rezultati pokazuju da se virulentni sojevi enterokoka i sojevi otporni na antimikrobne tvari pojavljuju u hrani životinjskog podrijetla $u$ Turskoj.

Ključne riječi: otpornost na antibiotike; sir; Enterococcus; gen tuf; virulencija 